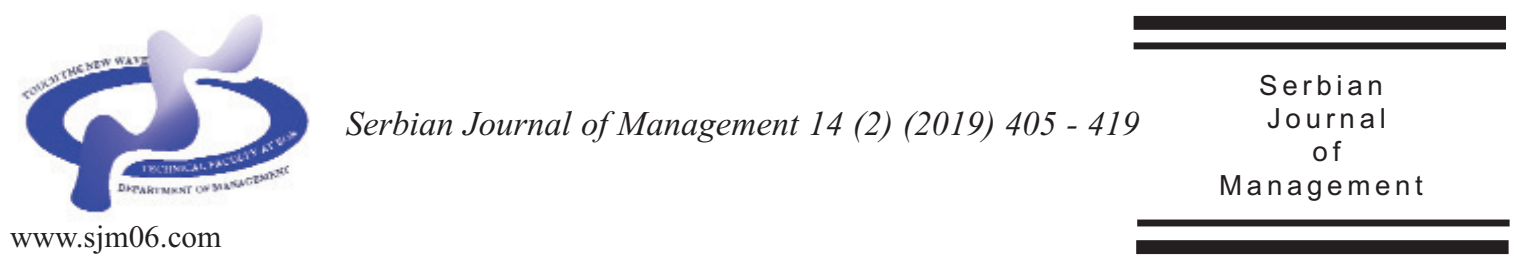

\title{
LIFESTYLES CONCEPTS AND ECOLOGICAL BEHAVIOR: AN EMPIRICAL STUDY IN INDIA
}

\author{
Asad Ahmad $^{\mathrm{a} *}$, Arham Adnan ${ }^{\mathrm{b}}$ and Mohammed Naved Khan ${ }^{\mathrm{b}}$

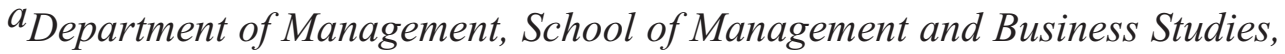 \\ Jamia Hamdard, New Delhi - 110062, India

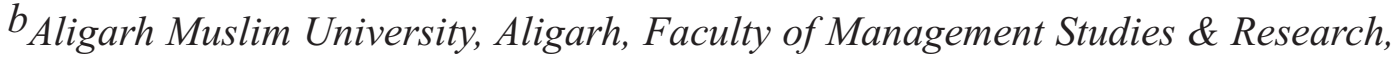 \\ Department of Business Administration, 202002 (UP), India
}

(Received 23 December 2017; accepted 10 September 2018)

\begin{abstract}
The constant issues related to the environment degradation faced by the world are thought to be reflected in the buying and consumption behavior of the consumers. The study of green consumer behavior is one of the vital present-day researches. The purpose of the present study is to explore the lifestyles of Indian consumers and their influence on the ecologically conscious behavior. For this purpose the researchers have employed the lifestyle scale along with the actual commitment subscale. The study results are based on researcher controlled student sample of 150 respondents. The data was analyzed using tools like SPSS 20.0 and AMOS 20.0. The results suggest that achievers and adventuresome are significant predictors of the ecological conscious behavior.
\end{abstract}

Keywords: lifestyles, green marketing, green consumer behavior, ecological behavior, India

\section{INTRODUCTION}

The increasing level of pollution has made the citizens of the country to give a hard and real thought to the environment around them and their day to day lifestyles. In this state of necessity, a study of the ecological lifestyles of a regular Indian consumer is plainly the need of the hour.
Going green is becoming increasingly attractive as a business strategy. As scientists and politicians debate the truth of global warming and dwindling natural resources, green industry practices not only enjoy favorable public sentiment but also increased cost savings, supportive government policies, and ever increasing profitability as well. Trends in consumption, government

* Corresponding author: asad7babar@gmail.com

DOI: $10.5937 /$ sjm14-16114 
policy, and costs all point towards even more green industry business opportunities in the years ahead (Franchise Help, 2016). Sixty four percent of consumers across the world claim that they try to have a positive impact on the environment on an everyday basis. A survey conducted in India revealed that, 96 percent of Indian respondents aged between 30 and 39 years agree that brands and companies have to be environmentally responsible (Statista, 2016).

The environmental concerns have had a great influence on the marketing strategies of leading firms across multiple industries over the globe, which include oil and gas, automobile, fast-moving consumer goods, cosmetics and personal care, food and health, aviation, utilities, etc. The past decade has also seen a number of green products and services gaining huge acceptance by consumers (Seuring \& Muller, 2008; Chan et al., 2012). The consumer behavior study has always been a complex task since there are many perspectives from which consumer behavior can be analysed (Fraj \& Martinez, 2006b; Ahmad \& Khan, 2015; Ahmad et al., 2017). Likewise, if we investigate the ecological consumer behavior we realise that it is also difficult to establish some limits that clearly define the consumer who is worried about the environment.

Lifestyles are psychographic variables that give firms a perfect orientation to identify the ecological consumer segment. In this sense, we find researches where psychographic variables have been used in defining the ecological consumer profile and has also revealed a significant relationship between psychographic variables and the ecological behavior (Ramanaiah et al., 1997; Fraj \& Martinez, 2006a; Adnan et al., 2017). Researchers claim that the green vision is a reality and needs to be more functionally understood to allow marketers to develop strategies aimed to meet the green consumers' needs (Adnan et al., 2017). In an increasingly globalized marketplace, there is evidence that knowledge of environmental issues, attitudes towards ecological problems, and environmentally friendly behavior varies across cultures (Laroche et al., 2002; Johnson et al., 2004). There is ample empirical evidence that environmental concern is a major factor in consumer decision making and has also been found to influence the lifestyles in one way or another (Zimmer et al., 1994; Kilbourne \& Beckmann, 1998; Adnan et al., 2017). In the present study we have attempted to analyse, which lifestyle variable best explains the ecological behavior pattern. In this context, we have considered a Lifestyle Scale, initially developed by $\mathrm{He}$ et al. (2010) and Ecological Behavior i.e. Actual Commitment subscale developed by Maloney et al. (1975).

\section{LITERATURE REVIEW}

Lifestyles are shaped by means of people's experiences and learning process (Kahle, 1996). Thus, people who behave in an environmental way, express their value of respect towards nature by having a positive attitude towards buying ecological products, recycling and taking part in activities that seek environmental protection (Fraj \& Martinez, 2006a). Lifestyles refer to distinctive patterns of living in its aggregate and broadest sense. They involve the economic level at which people live, spending patterns of their time and money, interests, and priorities in their lives (Anderson \& Golden, 1984). The concept of lifestyles is more comprehensive than that of demographic and socioeconomic 
characteristics (Blackwell et al., 2001), and individuals' lifestyle appears to be stronger predictors of consumer behavior, such as the ecological consumer behavior (Fraj \& Martinez, 2006a; Adnan et al., 2017).

The researches on green marketing and ecological consumer behavior started in the 1990s (Zimmer et al., 1994). Researchers have attempted to identify the factors that influence environmentally friendly behavior, including demographics (Diamantopoulos et al., 2003), environmental knowledge, attitudes (Chan, 2001), values (Ramayah et al., 2010), and internal and external moderators (Rylander \& Allen, 2001). The research on green consumption has also involved applying established theories and models, most commonly those based on the theory of reasoned action (Ajzen \& Fishbein, 1980) and the related theory of planned behavior (Ajzen, 1991). Numerous models attempt to incorporate both internal and external elements, including the model of environmental behavior (Hines et al., 1987), the attitude-behavior-context model (Stern, 2000), the models introduced by Rylander and Allen (2001) and Bagozzi et al. (2002). Likewise, if we investigate the ecological consumer behavior we realise that it is also difficult to establish the limits that clearly define the profile of the consumer who behaves in an environmentally friendly manner. Consequently, the measurement, the conceptual delimitation of this behavior and the identification of the ecological segment in the market are the key aspects that results in the assessment of a crucial aspect of a consumer's identity (Fraj \& Martinez, 2006b).

Studies have identified characteristics of people who are likely to exhibit Ecological Concerned Consumer Behavior (Passey \& Watt, 2002). These characteristics focus on (a) demographics including age, sex, income, education and place of residence, and (b) psychographics including political orientation, altruism, perceived customer effectiveness, and environmental concern. For the identification of the ecological consumers segment, there are several studies where researchers have tried to find the profile of these consumers. Diamantopoulos et al. (2003) comprehensively reviewed six socio-demographic variables (age, marital status, gender, number of children, education, and social class) and suggested that older and higher educated people are more likely to exhibit recycling behavior. Income is another positive predictor of green purchasing behavior (Kinnear et al., 1974). However, green behavior is almost independent of the influence of age and income (Gilg et al., 2005). A few studies even found a negative relationship between income and environmental concern/green behavior (Samdahl \& Robertson, 1989; Roberts, 1996).

Lifestyles have been used for explaining and predicting environmentally friendly behavior. And these studies have established a significant relationship among the lifestyles and ecological behavior (Haanpaa, 2007; Adnan et al., 2017). Lifestyles can play an important role in the consumer decision process, with regard to product choice and brand choice (Blackwell et al., 2012). They provide a powerful basis for understanding consumer behavior within and across cultures (Burgess \& Steenkamp, 1999), and are inextricably linked to consumer attitudes and influence their purchase behavior (Li \& Cai, 2012).

Ecologically conscious and environment friendly behavior has been extensively researched in western countries (Chan, 2001; Hartmann et al., 2005; Yeung, 2005; Fraj \& 
Martinez, 2006a, b; Rios et al., 2006; Chan et al., 2006; D'Souza et al., 2006; PickettBaker \& Ozaki, 2008) but research on environmental issues in India is still in the nascent stage (Adnan et al., 2017). Siringi (2012) examined green consumer behavior among highly educated consumers in India. Studies on preference for green products suggest that Indian consumers' involvement and environmental concern are important in predicting their intention to buy green products (Ishawini \& Datta, 2011). Existing literature recognizes relevance of factors like lifestyle, consumers' knowledge about green products, peer influence, and environmental concerns on purchase of environment friendly products. Infotech are increasingly investing in green initiatives. People are becoming conscious about environment and ecological products (Khare, 2014), however, there is very little research on Indian consumers' ecologically conscious behavior. Fraj and Martínez (2006a) posit that environmental concerns and self-fulfillment values characterise an ecological consumer who is environmentally conscious and has an ecological lifestyle. In similar vein, understanding Indian consumers' ecological concerns would provide useful insights for marketing green products. Exploring Indian consumers' ecological behavior and their lifestyles can provide valuable insights both to the marketers and the practitioners.

The researchers in the present study aim to study the lifestyle factors and their influence on the ecological behavior of the young consumers in India. For this purpose, a proposed research model with five different lifestyles (Figure 1), has been used to better explain the ecological behavior.

On the basis of this research framework, the following hypotheses were formulated:

H01: Need for uniqueness has a significant positive relationship with the ecological behavior.

H02: Price consciousness has a significant positive relationship with the ecological behavior.

H03: Public-interest orientation has a significant positive relationship with the ecological behavior.

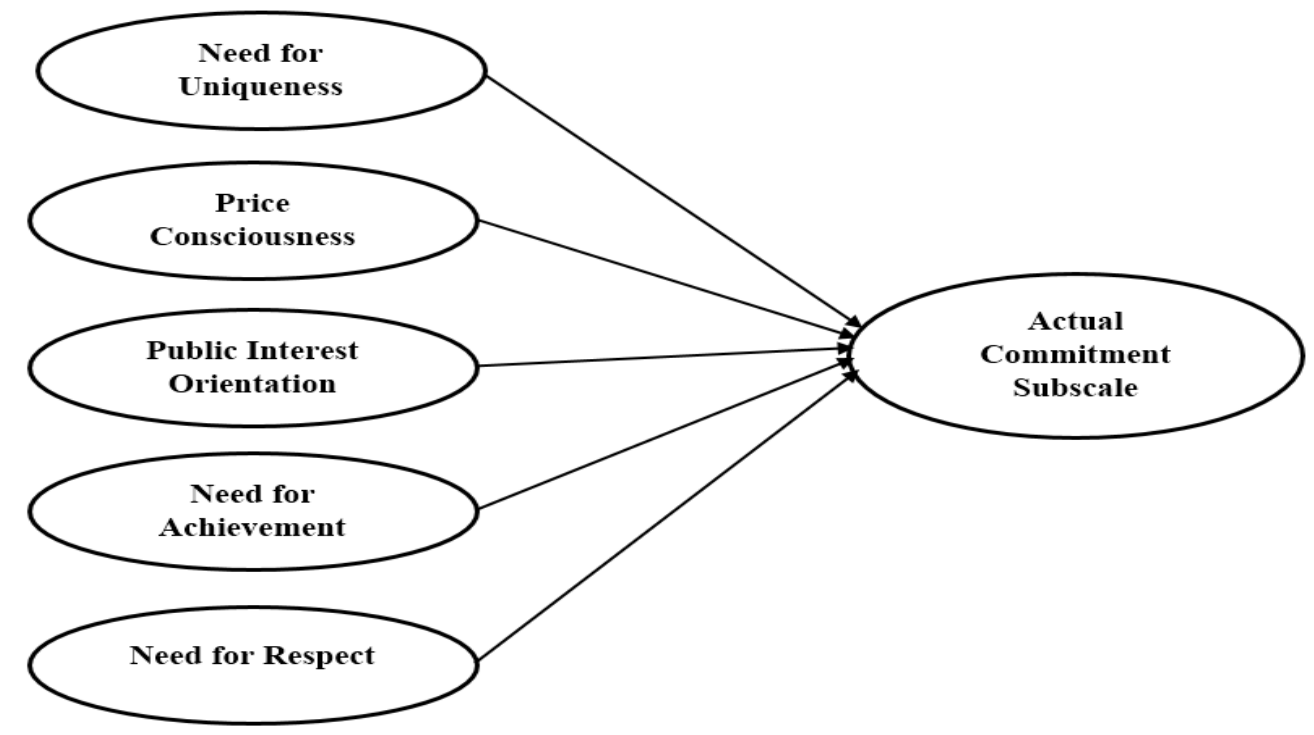

Figure 1. Research Framework 
H04: Need for achievement has a items (Fraj \& Martínez, 2006a) and Actual significant positive relationship with the Commitment subscale comprising 9 items ecological behavior.

H05: Need for respect has a significant positive relationship with the ecological behavior.

\section{RESEARCH METHODOLOGY}

Instrument Design: The scale used in the present study includes items explaining the lifestyle and the ecological concern (Table 1). It has actually been adapted from two scales viz. Lifestyle scale comprising 19 (He at al., 2010). The applicability of both the scales has been widely accepted. The responses of the consumers were engaged using an online questionnaire employing a 5point Likert scale (where $1=$ strongly disagree and $5=$ strongly agree).

The Sample: The sample of the present study comprised students from government funded premier institutions located in Delhi and National Capital Region (NCR) of India offering Under Graduate to Post-Doctoral Programs in higher education. Students in Delhi and NCR come from different parts of the country with different cultures (Khan et

\section{Table 1. Scale Used}

\begin{tabular}{ll}
\hline \multicolumn{1}{c}{ ITEM } & Code \\
\hline I have never actually bought a product while keeping in mind its polluting effect. & VR1 \\
I keep track of my government's initiatives on environment issues. & VR2 \\
I have contacted a local NGO/agency to find out what I can do about pollution. & VR3 \\
I make a special effort to buy products in recyclable packaging. & VR4 \\
I have attended a seminar/conference on improving the environment. & VR5 \\
I have switched products for ecological/environmental reasons. & VR6 \\
I have never joined a clean-up drive (eg. Swachh Bharat Abhiyan). & VR7 \\
I have never attended an environmental/ecological summit. & VR8 \\
I buy/subscribe environment related publications. & VR9 \\
I like to experiment with new ways of doing things. & VR10 \\
I always try to follow rules. @ & VR11 \\
I like leading edge and adventurous things. & VR12 \\
I like to take chances. & VR13 \\
I like to take adventures. & VR14 \\
I enjoy breaking out of the daily routine. & VR15 \\
I compare prices of at least a few brands before I choose one. & VR16 \\
If you can re-use an item you already have, there's no sense in buying something new. & VR17 \\
It is important for me to get the best prices for the products I buy. & VR18 \\
I find myself checking the prices even for small items. & VR19 \\
Economic growth should take preference over environmental considerations. & If asked, I would contribute time, money or both to improve the quality of the environment. \\
Humans must live in harmony/co-ordination with nature in order to survive. & VR21 \\
I need to feel a sense of accomplishment/achievement. & VR22 \\
I tend to set and strive to reach my goals. & VR23 \\
Getting things done is always on my to do list. & VR24 \\
I attempt to maintain a high status among my friends. & VR25 \\
I value a warm/sincere relationship with my family and friends. & VR26 \\
\hline
\end{tabular}


al., 2012; Ahmad \& Khan, 2017). The students in these institutions and regions belong to middle class strata of the society and reveals cosmopolitan outlook (Heslop, 2014; Kirmani \& Khan, 2016; Ahmad \& Khan, 2017). Further middle class strata of the society is considered to be the representative of the population (Shabnam, 2012; Ahmad et al., 2017). Hence, sample from the students of Delhi and NCR may be considered as surrogate for the whole population.

Data Collection: A researcher controlled sampling was employed to collect the data for this study. The respondents were first of all informed about the purpose of the study and interestingly many of them declined to respond. Out of the 200 filled questionnaires received, only 150 of them were deemed useful for further analysis, giving a response rate of $75 \%$. The sample comprised of 54 percent of males and 46 percent of females. The demographic profiles of the respondents are mentioned in Table 2.

\section{Table 2. Demographic Profile of Respondents}

\begin{tabular}{lc}
\hline & FREQUENCY \\
\hline QUALIFICATION & 81 \\
Graduates & 69 \\
Post graduate & \\
AGE & 72 \\
Less than 25 Years & 78 \\
Above 25 Years & \\
GENDER & 82 \\
Male & 68 \\
Female & \\
Source: Prepared by Researchers &
\end{tabular}

\section{ANALYSIS AND RESULTS}

\subsection{Exploratory Factor Analysis (EFA)}

EFA was performed using SPSS 20.0. The extraction for the data analysis was based on the principal component analysis with varimax rotation and Kaiser Normalization. The process of scale and item refinement was possible over repetitive iterations and as per the suggestions of Büyüköztürk et al., (2004) and Khan and Adil (2013) items with factor loadings less than $0.4(<0.4)$ were removed, resulting in a refined scale of 14 items. The analysis (rotated component matrix) yielded 4 factors namely Achievers (Need for Achievement), Ecoheads (Ecological Behavior), Adventuresome (Need for Uniqueness), and Economicals (Price Consciousness). The refining of the scale led to the deletion of two factors i.e. public interest orientation and need for respect which further led to the omission of two hypotheses (H03 and H05). The KaiserMeyer-Olkin (KMO) measure of sampling adequacy for the scale items showed a practical level of common variance with the KMO (0.807) greater than the suggested value of 0.6. The resultant factors signified a suitable $(66.59 \%)$ variance of the factors The EFA results are displayed in Table 3.

The Cronbach Alpha values for all the four variables were found to be above the minimum value of 0.6 (Hair et al., 1998; Kerlinger \& Lee, 2000; Khan \& Adil, 2013). The alpha value of the variable 'achievers', comprising 5 items was found to be 0.830 . The second variable 'Ecoheads', third variable 'Adventuresome' and fourth variable 'Economicals' comprising 3 items each had alpha value of $0.764,0.757$ and 0.717 , respectively. Thus, the scale was found to be reliable with the reliability of all the factors to be more than 0.7 .

The results of the EFA have certain limitations like we cannot explain theoretically the loadings of items on more than one factor although there is a correlation between the variables (Ahire et al., 1996). To 
overcome the limitations of EFA and to tested using a two-step Structural Equation understand the inter-relationships between Modeling (SEM) (Lee, 2008; Adil et al., the four factors retained after EFA, the 2013).

proposed research model (Figure 2) was

\section{Table 3. Results of EFA}

\begin{tabular}{lcc}
\hline \multicolumn{1}{c}{ Statements } & Factor Loadings & Construct Reliability \\
\hline ACHIEVERS & .788 & \\
Humans must live in harmony with nature in order to survive. & .754 & .830 \\
I value a warm/sincere relationship with my family. & .736 & .732 \\
I need to feel a sense of achievement. & .682 & \\
I tend to set and strive to reach my goals. & .836 \\
Getting things done is always on my to do list. & .806 \\
ECOHEADS & .800 \\
I have contacted a local NGO/agency to find out what I can do about. & .764 \\
Pollution & .799 \\
I have attended a seminar/conference on improving the environment. & .744 \\
I make a special effort to buy products in recyclable packaging. & .707 \\
ADVENTURESOME & \\
I like to experiment with new ways of doing things. & .766 \\
I like to take adventures. & .758 \\
I like to take chances. & .735 \\
ECONOMICALS & \\
I compare prices of at least a few brands before I choose one. & .717 \\
I check the prices even for small items. & \\
It is important for me to get the best prices for the products I buy. & Total Variance Explained: $66.59 \%$ \\
\hline \multicolumn{2}{c}{ BTS= 785.883} & \\
\hline Source: Prepared by Researchers &
\end{tabular}

Source: Prepared by Researchers

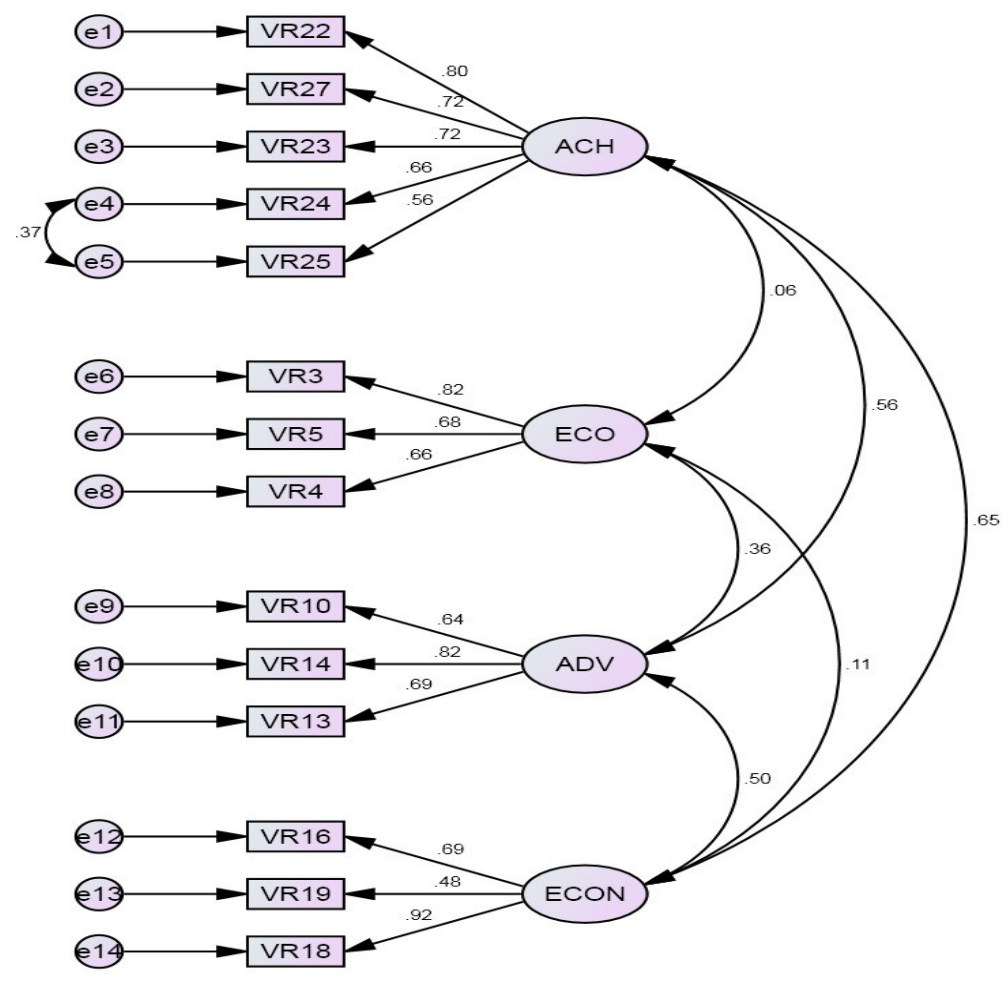

$(\mathrm{ACH}=$ Achievers $; \mathrm{ECO}=$ Ecoheads $; \mathrm{ADV}=$ Adventuresome $; \mathrm{ECON}=$ Economicals $)$

Figure 2. Proposed Research Model 


\subsection{Confirmatory Factor Analysis (CFA)}

The methodology suggested by Gerbing and Anderson (1988) has been applied to evaluate the proposed research model. CFA was performed using AMOS 20 on the four factors viz. Achievers, Ecoheads, Adventuresome and Economicals with the items loading on each factor were specified and the proposed model was then tested for model fit.

All the items with acceptable range of factor loadings loaded significantly on their corresponding variables (Figure 2). The standardized regression weights (Table 4) for all the items were found to be above the minimum criterion of 0.40 (Ford et al., 1986; Ryu et al., 2010). The Chi-square value was found to be 99.265 with 70 degrees of freedom $(p<0.05)$.

Table 4. Standardized Regression Weights (CFA)

\begin{tabular}{|c|c|}
\hline & Estimate \\
\hline VR22 $\leftarrow \mathrm{ACH}$ & .763 \\
\hline $\mathrm{VR} 27 \leftarrow \mathrm{ACH}$ & .695 \\
\hline $\mathrm{VR} 23 \leftarrow \mathrm{ACH}$ & .731 \\
\hline $\mathrm{VR} 24 \leftarrow \mathrm{ACH}$ & .714 \\
\hline $\mathrm{VR} 25 \leftarrow \mathrm{ACH}$ & .631 \\
\hline $\mathrm{VR} 3 \leftarrow \mathrm{ECO}$ & .824 \\
\hline VR5 $\leftarrow$ ECO & 679 \\
\hline $\mathrm{VR} 4 \leftarrow \mathrm{ECO}$ & .664 \\
\hline $\mathrm{VR} 10 \leftarrow \mathrm{ADV}$ & .640 \\
\hline $\mathrm{VR} 14 \leftarrow \mathrm{ADV}$ & .819 \\
\hline $\mathrm{VR} 13 \leftarrow \mathrm{ADV}$ & .684 \\
\hline $\mathrm{VR} 16 \leftarrow \mathrm{ECON}$ & .695 \\
\hline VR19 $\leftarrow \mathrm{ECON}$ & .485 \\
\hline VR18 $\leftarrow$ ECON & .916 \\
\hline
\end{tabular}

The overall model fit was found to be satisfactory with the value of GFI to be 0.914 , CFI to be 0.960 and the value of AGFI and NFI were found to be a bit less than that of 0.9 being 0.870 and 0.888 , respectively. The values of CMIN/DF (1.418) and RMSEA (.053) were also found to be within acceptable range. The overall summary of the key fit statistics for the proposed model is demonstrated in Table 5.

\section{Table 5. Model Fit Indices (CFA)}

\begin{tabular}{lcc}
\hline Fit Index & $\begin{array}{c}\text { Recommended } \\
\text { Values* }\end{array}$ & $\begin{array}{c}\text { Observed } \\
\text { Values }\end{array}$ \\
\hline CMIN/DF & $<3.0$ & 1.418 \\
GFI & $>0.90$ & .914 \\
AGFI & $>0.80$ & .870 \\
NFI & $>0.80$ & .888 \\
CFI & $>0.90$ & .960 \\
RMSEA & $<0.070$ & .053 \\
\hline
\end{tabular}

*Source: Hu and Bentler, 1999; Hooper et al., 2008; Hair et al., 2010; Malhotra and Dash, 2011

The scale was further verified for its validity and reliability all the four variables were evaluated using the composite reliability (CR) and average variance extracted (AVE) demonstrated in Table 6. All of the four variables had a desirable level of composite reliability ranging from (0.7530.834) which was above the minimum required value of 0.7 (Fornell \& Larcker 1981; Hair et al., 2010; Malhotra \& Dash, 2011), indicating an adequate reliability of the factors.

The average variance extracted (AVE) for the factors, Achievers, Ecoheads, Adventuresome and Economicals were found to be well above the minimum value of 0.5 which signified an acceptable convergent validity of the variables (Fornell \& Larcker 1981; O'Leary-Kelly \& Vokurka, 1998; Hair et al., 2010; Ryu et al., 2010; Khan \& Adil, 2013). The factors also showed an adequate discriminant validity (diagonal values highlighted in bold), as the square root of AVE for all the constructs is greater than the inter-construct correlation (Fornell 
Table 6. Reliability and Validity

\begin{tabular}{lllllll}
\hline & CR & AVE & ADV & ACH & ECO & ECON \\
\hline ADV & 0.760 & 0.516 & $\mathbf{0 . 7 1 8}$ & & & \\
ACH & 0.834 & 0.502 & 0.580 & $\mathbf{0 . 7 0 8}$ & & \\
ECO & 0.768 & 0.527 & 0.361 & 0.075 & $\mathbf{0 . 7 2 6}$ & \\
ECON & 0.753 & 0.519 & 0.502 & 0.640 & 0.114 & $\mathbf{0 . 7 2 0}$ \\
\hline \multicolumn{5}{l}{ Source: Prepared by Researchers }
\end{tabular}

\& Larcker 1981; O’Leary-Kelly \& Vokurka, 1998; Hair et al., 2010; Malhotra \& Dash, 2011; Khan \& Adil, 2013). Thus, the four variables were found to have adequate validity and reliability.

\subsection{Structural Model}

With the adequate results of CFA the researchers further proceeded with analysis of the proposed model and the hypotheses. The model fit indices were found to be within the acceptable range with CMIN/DF (1.658), GFI (.898), AGFI (.847), NFI (.917), CFI (.936), and RMSEA (.066). With Chisquare value being 116.080 and degrees of freedom being 70 with other model fit indices the overall structural model was found to be satisfactory. Summary of the

Table 7. Model Fit Indices (SEM)

\begin{tabular}{lcc}
\hline Fit Index & $\begin{array}{c}\text { Recommended } \\
\text { Values* }\end{array}$ & $\begin{array}{c}\text { Observed } \\
\text { Values }\end{array}$ \\
\hline CMIN/DF & $<3.0$ & 1.658 \\
GFI & $>0.90$ & .992 \\
AGFI & $>0.80$ & .884 \\
NFI & $>0.80$ & .860 \\
CFI & $>0.90$ & .989 \\
RMSEA & $<0.070$ & .054 \\
\hline
\end{tabular}

*Source: Hu and Bentler, 1999; Hooper et al., 2008;

Hair et al., 2010; Malhotra and Dash, 2011 model fit indices is presented in Table 7.

The relationship between Ecoheads and two factors Achievers and Adventuresome was found to be significant with a significance level of $P>0.05$, but the relationship between Ecoheads and Economicals was found to be insignificant. Figure 3 and Table 8 demonstrate the results of the structural model.

\section{DISCUSSION AND CONCLUSION}

\subsection{Summary of the Study}

In developing countries like India, the general literacy level has been found to be quite low thus, there is a need to educate the people about the environmental concerns which will help in changing their behavior (Khan et al., 2012). The objectives of the present study were to understand the role of various lifestyle factors on the ecological behavior. The researchers in the present study have used a 27-item lifestyle (5 factors) and ecological concern scale adapted from the study of He et al. (2010) and Fraj and Martínez (2006a), respectively. The researchers started with analyzing 5 lifestyle

Table 8. Standardized Regression Weights (SEM)

\begin{tabular}{lclcc}
\hline & & & Estimates & p- value \\
\hline Ecoheads & $\leftarrow$ & Achievers & .556 & .009 \\
Ecoheads & $\leftarrow$ & Adventuresome & .945 & .000 \\
Ecoheads & $\leftarrow$ & Economicals & .282 & .283 \\
\hline Source: Prerpared by Researchers
\end{tabular}




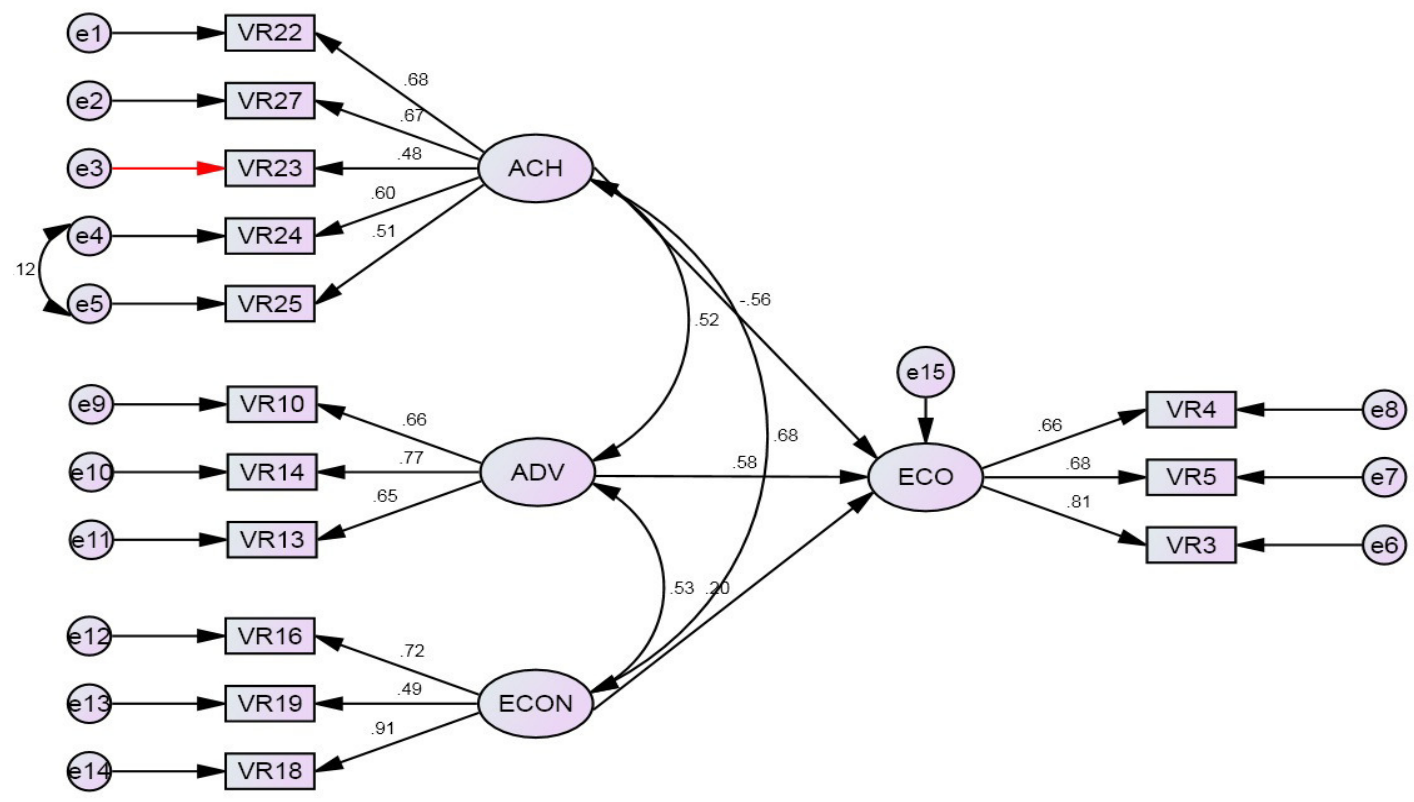

$(\mathrm{ACH}=$ Achievers $; \mathrm{ECO}=$ Ecoheads $; \mathrm{ADV}=$ Adventuresome $; \mathrm{ECON}=$ Economicals $)$

Figure 3. SEM on Proposed Model

factors (Need for uniqueness, Price consciousness, Public-interest orientation, Need for achievement and Need for respect) and the Actual commitment sub-scale. EFA was applied on the two scales to identify the relevant lifestyle factors determining the green consumer behavior (Churchil et al., 2010). The results of the EFA yielded three lifestyle constructs viz. Achievers (comprising three items from the need for achievement and one item each from need for respect and public-interest orientation), Adventuresome (comprised 3 items of need for uniqueness) and Economicals (comprising 3 items of price consciousness). The Ecoheads was left with three items of the 9-item actual commitment subscale related to ecological behavior. Thus the study yielded a short and refined lifestyle scale measuring the ecological behavior. Further the refined scale items were checked for the reliability, validity, goodness of fit using CFA and SEM. All the factor loadings and model fit indices were found to be satisfactory leading to a model fit. Further the results SEM brought up the role of the 3 lifestyle factors on the ecological behavior. The results suggested that both Achievers and Adventuresome are important predictors of Ecoheads. Further, adventuresome was found to have a strong significance compared to achievers. And interestingly, economicals, those who care a lot about prices of products and services, had no significant relationship with the ecoheads. Thus, proving that the price of the products matters, even when the products are environment-friendly. This result was in line with the results in the study of Prakash (2002). Green consumption or sustainable consumption is actually a result of consumers moving towards sustainable lifestyles (Gilg et al., 2005).

\subsection{Implications}

A significant contribution of the study is that it suggests a lifestyle approach for 
measuring the green consumer behavior. The results in the present study suggest that the achievers and the adventuresome emerged as predictors significant at 0.009 and 0.000 levels, respectively. Thus, there are two major academic contribution of this study. Firstly, the present study had tried to account the role of the lifestyle in the perception of ecological behavior. Secondly, this study demonstrates that Achievers and the Adventuresome are the ones who significantly predict the Ecoheads. The intricate role of factors like psychographic and demographics of the consumers makes it difficult for the marketers to measure the ecological behavior of the consumers. The results of this study are significantly important for both the academicians and the marketers. The green marketers and policy makers must understand the relationship of various lifestyles and the ecological friendliness. The marketers need to develop promotional strategies which can change the approach of people of different lifestyle group towards the sustainability of the environment by adopting products and services which are ecologically friendly.

\section{LIMITATIONS AND DIRECTIONS FOR FUTURE RESEARCH}

Like other researches, this study may have also suffered from certain limitations. The use of convenient sampling may have limited the generalizability of the results of the study. The study was based on graduate and postgraduate students of a particular region of India which may also have hampered the generalizability of the study results. The study has exclusively focused on the individual perceptions and dispositions rather than on situational factors. However, the above mentioned limitations of the study are likely indicators for various other new areas of research. The results of the study can be further validated on larger and different samples. The results may also be validated in other countries enabling cross-cultural comparison. Various other occupational and educational groups need to be worked upon in the context of green consumer behavior which might broaden the scope of the findings of the study.

\section{References}

Adil, M., Akhtar, A., \& Khan, M.N. (2013). Refinement of internet banking service quality scale: a confirmatory factor analysis approach. International Journal of Services and Operations Management, 14 (3), 336-354.

Adnan, A., Ahmad, A., \& Khan, M.N. (2017). Examining the role of consumer lifestyles on ecological behavior among young Indian consumers. Young Consumers, 18 (4), 348-377.

Ahire, S.L., Golhar, D.Y., \& Waller, M.A. (1996). Development and validation of TQM implementation constructs. Decision Sciences, 27 (1), 23-56.

Ahmad, A., \& Khan, M.N. (2015). Mapping online buyer behavior: A critical review of empirical studies. Pacific Business Review International, 8 (2), 37-48.

Ahmad, A., Rahman, O., \& Khan, M.N. (2016). Consumer's perception of website service quality: An empirical study. Journal of Internet Commerce, 15 (2), 125-141.

Ahmad, A., \& Khan, M.N. (2017). Developing a website service quality scale: A confirmatory factor analytic approach. Journal of Internet Commerce, 16 (1), 104126. 


\title{
КОНЦЕПТИ ЖИВОТНОГ СТИЛА И ЕКОЛОШКО ПОНАШАҢЕ: ЕМПИРИЈСКА СТУДИЈА У ИНДИЈИ
}

\author{
Asad Ahmad, Arham Adnan, Mohammed Naved Khan
}

\section{Извод}

Сматра се да стална питања везана за деградацију животне средине, са којом се свет суочава, утичу на понашање купаца при куповини и потрошњи. Проучавање понашања “зеленог” потрошача једно је од виталних истраживања у данашње време. Сврха ове студије је истраживање животног стила индијских потрошача и њихов утицај на еколошки свесно понашање. У ту сврху, истраживачи су користили скалу животног стила заједно са подскалом стварне посвећености. Резултати студије заснивају се на узорку од 150 студената, при чему је узорак контролисан од стране истраживача. Подаци су анализирани помоћу алата као што су „SPSS“ 20.0 и „AMOS“ 20.0. Резултати сугеришу да су достигнућа и склоност авантуризму значајни предиктори еколошки свесног понашања.

Кључне речи: животни стил, зелени маркетинг, понашање зеленог потрошача, еколошко понашање, Индија

Ahmad, A., Rahman, O., \& Khan, M.N. Western Thomas Learning. Mason, OH, (2017). Exploring the role of website quality USA. and hedonism in the formation of esatisfaction and e-loyalty: Evidence from internet users in India. Journal of Research in Interactive Marketing, 11 (3), 246-267.

Ajzen, I., \& Fishbein, M. (1980). Understanding attitudes and predicting social behaviour. 1 Behavior, Prentice Hall, Englewood Cliffs, NJ

Ajzen, I. (1991). The theory of planned behavior. Organizational Behavior and Human Decision Processes, 50 (2), 179-211.

Anderson, W.T., \& Golden, L.L. (1984). Lifestyle and psychographics: A critical review and recommendation. Kinnear, $\mathrm{T}$. (Ed.), Advances in Consumer Research, 11, Association for Consumer Research, Provo, 405-411.

Bagozzi, R.P., Gürhan-Canli, Z., \& Priester, J. (2002). The Social Psychology of Consumer Behaviour. Open University Press,. Buckingham, United Kingdom.

Blackwell, R.D., Miniard, P.W., \& Engel, J.F. (2001). Consumer Behavior. South-
Blackwell, R.D., Miniard, P.W., \& Engel, J.F. (2012). Consumer Behavior. Cengage Learning Asia Pvt. Ltd, Singapore.

Burgess, S.M., \& Steenkamp, J.E.M. (1999). Values priorities and consumer behavior in a transitional economy. In: Batra, R. (Ed.), Marketing Issues in Transitional Economics. Kluwer Academic Press, Norwell, MA, 85-105.

Büyüköztürk, Ş., Akgün, Ö.E., Özkahveci, Ö., \& Demirel, F. (2004). The validity and reliability study of the Turkish version of the motivated strategies for learning questionnaire. Educational Sciences: Theory \& Practice, 4 (2), 207-239.

Chan, H.K., He, H., \& Wang, W.Y. (2012). Green marketing and its impact on supply chain management in industrial markets. Industrial Marketing Management, 41 (4), 557-562.

Chan, R.Y. (2001). Determinants of Chinese consumers' green purchase behavior. Psychology \& Marketing, 18 (4), 
389-413.

Chan, R.Y.K., Leung, T.K.P., \& Wong, Y.H. (2006). The effectiveness of environmental claims for services advertising. Journal of Services Marketing, 20 (4), 233-250.

Churchill, G. A., Iacobucci, D., \& Israel, D. (2010). Marketing research: A south Asian perspective. Cengage Learning, New Delhi.

D’Souza, C., Taghian, M., \& Lamb, P. (2006). An empirical study on the influence of environmental labels on consumers. Corporate Communications: An International Journal, 11 (2), 162-173.

Diamantopoulos, A., Schlegelmilch, B.B., Sinkovics, R.R., \& Bohlen, G.M. (2003). Can socio-demographics still play a role in profiling green consumers? A review of the evidence and an empirical investigation. Journal of Business Research, 56 (6), 465480.

Ford, J.K., MacCallum, R.C., \& Tait, M. (1986). The application of exploratory factor analysis in applied psychology: A critical review and analysis. Personnel Psychology, 39 (2), 291-314.

Fornell, C., \& Larcker, D. F. (1981). Evaluating structural equation models with unobservable variables and measurement error. Journal of marketing research, 18(1), 39-50.

Fraj, E., \& Martinez, E. (2006a). Environmental values and lifestyles as determining factors of ecological consumer behaviour: an empirical analysis. Journal of Consumer Marketing, 23 (3), 133-144.

Fraj, E., \& Martinez, E. (2006b). Influence of personality on ecological consumer behaviour. Journal of Consumer Behaviour, 5 (3), 167-181.

Gerbing, D.W., \& Anderson, J.C. (1988). An updated paradigm for scale development incorporating unidimensionality and its assessment. Journal of Marketing Research, 25 (2), 186-192.

Gilg, A., Barr, S., \& Ford, N. (2005). Green consumption or sustainable lifestyles? Identifying the sustainable consumer. Futures, 37 (6), 481-504.

Haanpaa, L. (2007). Consumers' green commitment: indication of a postmodern lifestyle? International Journal of Consumer Studies, 31(5), 478-486.

Hair, J.F., Anderson, R.E., Tatham, R.L., \& Black, W.C. (1998). Multivariate Data Analysis (5th ed.). Englewood Cliff. New Jersey, USA.

Hair, J.F., Anderson, R.E., Babin, B.J., \& Black, W.C. (2010). Multivariate data analysis: A global perspective (Vol. 7). Pearson, Upper Saddle River, NJ.

Hartmann, P., Ibáñez, V. A., \& Sainz, F.J.F. (2005). Green branding effects on attitude: functional versus emotional positioning strategies. Marketing Intelligence and Planning, 23 (1), 9-29.

He, Y., Zou, D., \& Jin, L. (2010). Exploiting the goldmine: a lifestyle analysis of affluent Chinese consumers. Journal of Consumer Marketing, 27 (7), 615-628.

Heslop, L. (2014). Understanding India: The future of higher education and opportunities for international cooperation. British Council.

Hines, J.M., Hungerford, H.R., \& Tomera, A.N. (1987). Analysis and synthesis of research on responsible environmental behavior: a meta analysis. The Journal of Environmental Education, 18 (2), 1-8.

Hooper, D., Coughlan, J.,\& Mullen, M.: Structural Equation Modelling: Guidelines for Determining Model Fit. Electronic Journal of Business Research Methods, 6 (1), 53-60.

Hu, L.T., \& Bentler, P.M. (1999). Cutoff 
criteria for fit indexes in covariance structure analysis: Conventional criteria versus new alternatives. Structural Equation Modeling: A Multidisciplinary Journal, 6 (1), 1-55.

Ishawini \& Datta, S.K. (2011). Proenvironmental concerns influencing green buying: a study on Indian consumers. International Journal of Business and Management, 6 (6), 124-133.

Johnson, C.Y., Bowker, J.M., \& Cordell, H.K. (2004). Ethnic variation in environmental belief and behavior: An examination of the new ecological paradigm in a social psychological context. Environment and Behavior, 36 (2), 157-186.

Kahle, L.R. (1996). Social values and consumer behavior: Research from the list of values. In Seligman, C., Olson, J.M., \& Zanna, M.P. (eds.), The psychology of values: The Ontario symposium, 8, 135-151.

Kerlinger, F.N., \& Lee, H.B. (2000). Foundations of Behavioral Research, 4th ed. Harcourt College Publishers, Orlando.

Khan, A., Khan, M.N., \& Adil, M. (2012). Exploring the new ecological paradigm (NEP) scale in India: Item analysis, factor structure and refinement. Asia-Pacific Journal of Management Research and Innovation, 8 (4), 389-397.

Khan, M.N., \& Adil, M. (2013). Data analysis techniques in service quality literature: Essentials and advances. Serbian Journal of Management, 8 (1), 95-112.

Khare, A. (2014). Consumers' susceptibility to interpersonal influence as a determining factor of ecologically conscious behaviour. Marketing Intelligence \& Planning, 32 (1), 2-20.

Kilbourne, W.E., \& Beckmann, S.C. (1998). Review and critical assessment of research on marketing and the environment. Journal of Marketing Management, 14 (6), 513-532.
Kinnear, T.C., Taylor, J.R., \& Ahmed, S.A. (1974). Ecologically concerned consumers: who are they? The Journal of Marketing, 38 (2), 20-24.

Kirmani, M.D., \& Khan, M.N. (2016). Environmental concern to attitude towards green products: evidences from India. Serbian Journal of Management, 11 (2), 159179.

Lee, N. (2008). Developing and validating an instrument to assess performance of public sector organisations: A case study of Malaysian schools. Measuring Business Excellence, 12 (3), 5675.

Li, M., \& Cai, L.A. (2012). The effects of personal values on travel motivation and behavioral intention. Journal of Travel Research. 51 (4), 473-487.

Laroche, M., Tomiuk, M.-A., Bergeron, J., \& Barbaro-Forleo, G. (2002). Cultural differences in environmental knowledge, attitudes, and behaviours of Canadian consumers. Canadian Journal of Administrative Sciences, 19 (3), 267-282.

Franchise Help. (2016, May 3). Green industry analysis 2016 - cost \& trends. Retrieved from https://www.franchisehelp.com/industryreports/green-industry-report/.

Malhotra, N,K., \& Dash. S. (2011). Marketing Research: An Applied Orientation (6th Ed.). Pearson. Noida, USA.

Maloney, M.P., Ward, M.P., \& Braucht, G.N. (1975). A revised scale for the measurement of ecological attitudes and knowledge. American Psychologist, 30 (7), 787-790.

O'Leary-Kelly, S. W., \& J. Vokurka, R. (1998). The empirical assessment of construct validity. Journal of operations management, 16(4), 387-405.

Passey, R., \& Watt, M. (2002). Review of 
Australian green power schemes. Australian CRC for Renewable Energy, Murdoch University, Perth, WA

Pickett-Baker, J., \& Ozaki, R. (2008). Pro-environmental products: marketing influence on consumer purchase decision. Journal of Consumer Marketing, 25 (5), 281293.

Prakash, A. (2002). Green marketing, public policy and managerial strategies. Business strategy and the Environment, 11 (5), 285-297.

Ramanaiah, N.V., Sharpe, J.P., \& Byravan, A. (1997). Type A behavior and the five-factor model of personality. Psychological Reports, 81 (2), 368-370.

Ramayah, T., Lee, J.W.C., \& Mohamad, O. (2010). Green product purchase intention: Some insights from a developing country. Resources, Conservation and Recycling, 54 (12), 1419-1427.

Rios, F.M., Martinez, T.L., Moreno, F.F., \& Soriano, P.C. (2006). Improving attitudes toward brands with environmental associations: an experimental approach. The Journal of Consumer Marketing, 23 (1), 2634.

Roberts, J.A. (1996). Green consumers in the 1990s: implications for advertising profile. Journal of Business Research, 36 (3), 217-231.

Rylander, D., \& Allen, C. (2001). Understanding Green Consumption Behavior: Toward an Integrative Framework. In Krishnan, R., \& Viswanathan, M. (Eds.) American Marketing Association Winter Educators' Conference Proceedings, 11, 386387.

Ryu, K., Han, H., \& Jang, S. (2010). Relationships among hedonic and utilitarian values, satisfaction and behavioral intentions in the fast-casual restaurant industry. International Journal of Contemporary
Hospitality Management, 22 (3), 416-432.

Samdahl, D.M., \& Robertson, R. (1989). Social determinants of environmental concern. Environment and Behavior, 21 (1), 57-81.

Seuring, S., \& Müller, M. (2008). From a literature review to a conceptual framework for sustainable supply chain management. Journal of Cleaner Production, 16 (15), 1699-1710.

Shabnam, S. (2012). The Indian middle class, the state and development: An enquiry into the broad claims of shifts in neo-liberal India. Inclusive: A Journal of Kolkata Centre for Contemporary Studies, 1 (1). Available online at: http://theinclusive.org/index-201201.html.

Siringi, R.K. (2012). Determinants of green consumer behavior of post graduate teachers. Journal of Business and Management, 6 (3), 19-25.

Statista. (2016, November 15). Consumer agreement towards brands and companies having a responsibilty to the environment in India as of summer 2014, by age group. Retrieved from Energy \& Environmental $\begin{array}{lllllllll}\mathrm{S} & \mathrm{e} & \mathrm{r} & \mathrm{v} & \mathrm{i} & \mathrm{c} & \mathrm{e} & \mathrm{s} & \text { : }\end{array}$ https://www.statista.com/statistics/555673/o pinions-environmental-responsibilitybrands-companies-india-by-age-group/

Stern, P.C. (2000). New environmental theories: toward a coherent theory of environmentally significant behavior. Journal of Social Issues, 56 (3), 407-424.

Yeung, S.P. (2005). Teaching approaches in geography and students' environmental attitudes. The Environmentalist, 24 (1), 101117.

Zimmer, M.R., Stafford, T.F., \& Stafford, M.R. (1994). Green issues: dimensions of environmental concern. Journal of Business Research, 30 (1), 63-74. 